\title{
Occurrence of Passiflora Latent Carlavirus in Cultivated and Wild Passiflora Species in Australia
}

R. D. Pares, L. V. Gunn, and E. N. Keskula, NSW Agriculture, Biological \& Chemical Research Institute, PMB 10, Rydalmere, NSW 2116, Australia; A. B. Martin, Royal Botanic Gardens, Mrs. Macquaries Rd., Sydney, NSW 2000, Australia; and D. S. Teakle, Department of Microbiology, University of Queensland, Brisbane, Qld. 4072, Australia

\begin{abstract}
Pares, R. D., Gunn, L. V., Keskula, E. N., Martin, A. B., and Teakle, D. S. 1997. Occurrence of Passiflora latent carlavirus in cultivated and wild Passiflora species in Australia. Plant Dis. $81: 348-350$.

A carlavirus was found to be widespread in commercial passionfruit (Passiflora edulis) plantings in New South Wales and Queensland. The particles observed were flexuous rods with mean dimensions of $651 \times 12 \mathrm{~nm}$. The particles often occurred in cells as aggregates but were never associated with pinwheel inclusion bodies, as is typical with passionfruit woodiness potyvirus. The particles showed a strong affinity (by immunoelectron microscopy) for antiserum prepared against Passiflora latent carlavirus (PLV) from Germany but increasingly less affinity for antisera against potato viruses $S$ and M and PLV from the United States. Survey results indicated that PLV has been present in Australian passionfruit for more than 10 years and is widespread in most commercial cultivars in New South Wales and Queensland. The virus was twice found in wild Passiflora suberosa, once in wild P. subpeltata, and once in a feral seedling of $P$. edulis near an infected planting of $P$. edulis.
\end{abstract}

Three viruses are recorded infecting passionfruit (Passiflora edulis Sims) in Australia: passionfruit woodiness potyvirus (PWV; 15,16), cucumber mosaic cucumovirus (CMV; 5,8,16), and passionfruit rhabdovirus (PRV; 11). A mixed infection of CMV and PWV has been associated with passionfruit tip necrosis (PTN) disease on the far north coast of New South Wales (13). PWV is universal in most commercial passionfruit cultivars in Australia and also occurs in wild Passiflora spp. (15).

In 1985 and 1993, during monitoring of passionfruit plants for viruses associated with PTN by electron microscopy, we saw some virions that were shorter and less flexuous than PWV particles, i.e., that resembled a carlavirus more than a potyvirus. Only one carlavirus has been reported to occur naturally in Passiflora spp., i.e., Passiflora latent virus (PLV) in P. coerulea L. and P. suberosa L. in Germany (2) and in Passiflora $\times$ Incense, a sterile hybrid of $P$. incarnata L. $\times$ P. cincinnata Masters, in the United States (14). In Florida, the virus has been transmitted experimentally to $P$. edulis f. edulis, P. edulis f. flavicarpa De-

Corresponding author: D. S. Teakle

E-mail: teakle@biosci.uq.oz.au

Send reprint requests to D. S. Teakle.

Accepted for publication 9 December 1996.

Publication no. D-1997-0204-06R

(C) 1997 The American Phytopathological Society gener, $P$. foetida L., and $P$. incarnata, in all of which it induced an inconspicuous, systemic foliar mosaic. In Germany and Florida, PLV virions were slightly flexuous rods with a normal length of $650 \mathrm{~nm}$ (2) or $651 \mathrm{~nm}(14)$, and the virus was mechanically transmitted to Chenopodium amaranticolor Coste \& Reyn. and C. quinoa Willd., inducing local chlorotic lesions and systemic chlorosis. Cytopathology of systemically infected $C$. quinoa was studied in detail (1).

As PLV has only been recorded in Germany and Florida, and has not been reported as occurring naturally in P. edulis, we investigated whether PLV occurred in passionfruit and other Passiflora spp. in Australia.

\section{MATERIALS AND METHODS}

Source of antisera. The following antisera were used: anti-PLV (a.PLV-g) donated by $\mathrm{C}$. Wetter (University of the Saarland, Saarbrucken, Germany); a.PLV-f donated by M. S. Elliott (University of Florida, Gainesville); antipotato virus $\mathrm{S}$
(a.PVS) and antipotato virus M (a.PVM), both from the American Type Culture Collection; and a.CMV and normal rabbit serum (NRS) made in our laboratories.

Immunological testing. Samples were prepared for immunoelectron microscopy (IEM) by our reported method (12). Particles were trapped for $4 \mathrm{~h}$ with $1 / 1,000$ dilution of the antiserum and then decorated for 15 min with a $1 / 32$ dilution of the antiserum before washing and staining with $2 \%$ ammonium molybdate. The grids were then examined in a Philips EM300 electron microscope.

Double antibody sandwich enzymelinked immunosorbent assay (DASELISA) was performed as described by Clark and Adams (3) using $1 \mu \mathrm{g}$ of purified IgG from a.PLV-g per $\mathrm{ml}$ for conjugate and coating antisera. Absorbances of reactions in Immulon 2 plates were read with a Titertek Multiskan MS2 spectrophotometer. An absorbance at $A_{405}$ of 0.10 or more was considered to be positive; control values were 0.03 or less.

Particles were measured from electron micrographs of the IEM samples. Micrographs of tomato mosaic tobamovirus (ToMV) were taken before and after those of the carlavirus, to act as a calibration standard. The length of ToMV was taken as $300 \mathrm{~nm}(6)$.

Serological relationships with other carlaviruses were determined by counts of particles trapped (10) by a.PLV-g, a.PLV-f, a.PVS, and NRS after an acquisition time of $4 \mathrm{~h}$. Four dilutions of virus-infected sap $\left(10^{0}, 10^{-1}, 10^{-2}\right.$, and $10^{-}$ ${ }^{3}$ ) were used with three antisera and a normal serum, and counts for each were averaged over 10 randomly selected fields. Particle decoration (9) was assessed using a.PLV-g, a.PLV-f, a.PVS, a.PVM, a.CMV, and NRS. Particles trapped by antisera were decorated by
Table 1. Comparison of antisera used to trap virus particles of a carlavirus from infected passionfruit leaves ${ }^{\mathrm{a}}$

\begin{tabular}{ccccc}
\hline \multirow{2}{*}{$\begin{array}{c}\text { Antigen dilution } \\
\left(\log _{\mathbf{1 0}}\right)\end{array}$} & \multicolumn{4}{c}{ Means of particle counts } \\
\cline { 2 - 5 } & a.PLV-g & a.PVS & a.PLV-f & Normal serum \\
\hline 0 & $>240^{\mathrm{b}}$ & 34 & $<1$ & 4 \\
-1 & 167 & 36 & $<1$ & $<1$ \\
-2 & 16 & 7 & $<1$ & $<1$ \\
-3 & 1 & 2 & 1 & 1 \\
\hline
\end{tabular}

a PLV = Passiflora latent carlavirus, PVS $=$ potato virus $\mathrm{S}$.

${ }^{b}$ Figures are means of 10 counts from randomly selected fields after trapping for $4 \mathrm{~h}$. 
floating the grids on drops of the antisera diluted $1 / 16$ and $1 / 32$ for $15 \mathrm{~min}$.

Surveys. In 1985, about 150 passionfruit samples from New South Wales were examined by electron microscopy, including some by IEM using trapping with a.PVS. In 1994 and 1995, a wider survey of Passiflora spp. was undertaken. In this survey, samples from a total of 254 plants in northern New South Wales and Queensland were tested for PLV using IEM and ELISA with a.PLV-g. Usually groups of up to seven similar plants were screened for PLV using ELISA, and then plants in positive groups were tested individually by IEM.

Inoculations. Inoculations were done by macerating infected tissue in $1 \% \mathrm{~K}_{2} \mathrm{HPO}_{4}$ containing a small amount of Celite as an abrasive. The resulting suspension solution was rubbed onto the leaves of $C$. quinoa, which were immediately washed with tap water.

Electron microscopy. Small pieces of infected passionfruit leaf tissue were fixed in 3\% glutaraldehyde (in $0.1 \mathrm{M}$ cacodylate buffer) overnight, given a postfixation treatment in $2 \% \mathrm{OsO}_{4}$ in the same buffer for $2 \mathrm{~h}$, en bloc stained with $2 \%$ uranyl acetate, dehydrated in a graded ethanol series, and then infiltrated with acetone, acetone/Spurr's resin, and finally Spurr's resin in molds. Ultrathin sections were cut using a Reichert OMU3 microtome with a diamond knife and stained with uranyl acetate and lead citrate before being examined in the transmission electron microscope.

\section{RESULTS}

Identification. The mean length of 89 particles trapped from $P$. edulis was 651 $\mathrm{nm}$ (Standard error of mean $=6.13)$, which puts it in the range for carlaviruses (7). The results of particle acquisition tests clearly showed a strong affinity for antiserum against the German isolate of PLV (PLV$\mathrm{g}$ ), whereas a.PVS had a moderate affinity for particles and a.PLV-f and NRS had none (Table 1).

Decoration of particles with antisera showed a similar pattern as above and is illustrated for 1/32 dilutions of a.PLV-g, a.PVS, a.PLV-f, and NRS (Fig. 1A to D). The only heavy decoration was shown by a.PLV-g, whereas a.PVS produced moderate decoration. The Florida antiserum, a.PLV-f, gave a light decoration at a concentration of $1 / 16$ (not illustrated).

Electron microscopy of thin sections showed large aggregates of elongated particles that resembled those reported for PLV (1). No pinwheel or cylindrical inclusions typical of a potyvirus infection were found in the same cells.

Inoculations. Infection rates of $C$. quinoa in inoculation tests were very low, only one plant from many repeated attempts developing chlorotic local lesions and a systemic chlorosis. Carlavirus-like particles were found in extracts of the infected tissue using IEM with a.PLV-g.

Incidence. In 1985, we recorded 70 passionfruit samples from New South Wales in which there were particles that were shorter and less flexuous than PWV (data
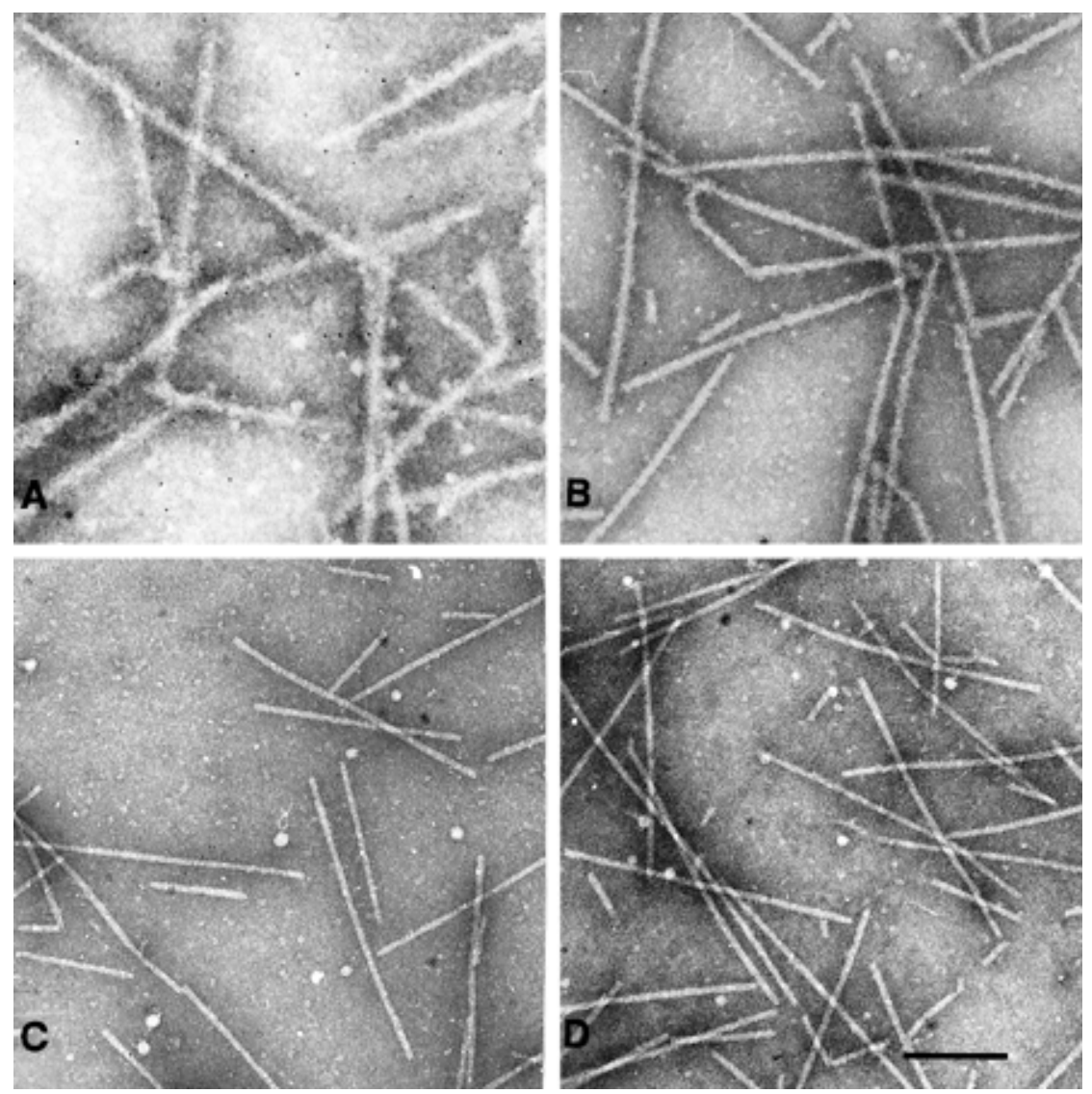

Fig. 1. Comparison of reactions between the Australian isolate of Passiflora latent virus (PLV) and antisera against three carlaviruses, (A) a.PLV-g, (B) antipotato virus S (a.PVS), and (C) a.PLV-f, and (D) normal serum. Particles were trapped for $4 \mathrm{~h}$ with a.PLV-g and then treated with 1/32 dilutions of the four sera for $15 \mathrm{~min}$ before washing and staining with $2 \%$ aqueous ammonium molybdate. Bar represents $200 \mathrm{~nm}$.

Table 2. Occurrence of Passiflora latent carlavirus (PLV) in Passiflora samples in 1994 and 1995

\begin{tabular}{|c|c|c|c|}
\hline \multirow[b]{2}{*}{ Species } & \multicolumn{3}{|c|}{ Plants positive for $\mathrm{PLV}$} \\
\hline & New South Wales & Queensland & Totals \\
\hline \multicolumn{4}{|l|}{ P. edulis f. edulis } \\
\hline Grafted cultivars & $50 / 80^{\mathrm{a}}$ & $43 / 61$ & $93 / 141$ \\
\hline Seedling plants & & $1 / 15$ & $1 / 15$ \\
\hline \multicolumn{4}{|l|}{ P. edulis f. flavicarpa } \\
\hline cv. Panama ${ }^{\mathrm{b}}$ & & $0 / 21$ & $0 / 21$ \\
\hline $\begin{array}{l}\text { Unnamed seedling }{ }^{c} \\
\text { (field grown) }\end{array}$ & & $3 / 3$ & $3 / 3$ \\
\hline $\begin{array}{l}\text { Unnamed seedling }{ }^{\mathrm{d}} \\
\text { (glasshouse grown) }\end{array}$ & & $0 / 6$ & $0 / 6$ \\
\hline P. foetida & & $0 / 23$ & $0 / 23$ \\
\hline P. ligularis & & $0 / 3$ & $0 / 3$ \\
\hline P. quadrangularis & & $0 / 3$ & $0 / 3$ \\
\hline P. suberosa & & $2 / 18$ & $2 / 18$ \\
\hline P. subpeltata & $0 / 8$ & $1 / 13$ & $1 / 21$ \\
\hline Total & $50 / 88$ & $50 / 166$ & $100 / 254$ \\
\hline
\end{tabular}

a All samples were analyzed by immunoelectron microscopy using antiserum to PLV-g. Numerator is number of plants positive; denominator is total number of plants tested.

b Seedling plants grown in the field away from PLV-infected P. edulis f. edulis.

c Seedling plants grown in the field close to PLV-infected P. edulis f. edulis.

$\mathrm{d}$ Seedlings (small) grown in a glasshouse from seed of a PLV-infected plant. 
negatively stained preparations of New South Wales passionfruit in 1993.

Survey results of 1994 and 1995 (Table 2) show that most commercial grafted plants of $P$. edulis f. edulis were infected with PLV, whereas seedling plants of $P$. edulis f. edulis were only rarely infected. Every commercial planting of $P$. edulis $\mathrm{f}$. edulis had at least one infected plant; usually all plants tested were positive for PLV.

With $P$. edulis f. flavicarpa, all cv. Panama seedling plants growing on farms without PLV-infected $P$. edulis f. edulis were free of PLV, whereas three plants of unnamed lines that were field-grown for several years in association with infected $P$. edulis f. edulis were infected with PLV. Six glasshouse-grown seedling progeny of the PLV-infected $P$. edulis f. flavicarpa vines were tested and were free of the virus.

In the case of other Passiflora species, most of the samples were free of PLV (Table 2). Only the naturalized species $P$. suberosa (2/18 infected) and $P$. subpeltata Ortega (1/22 infected) contained the virus.

\section{DISCUSSION}

A comparison of previous serological studies involving PLV and other carlaviruses $(2,4,14)$ indicates that the German isolate of PLV is closely related to PVS but less so to PVM (a difference in titer of five twofold dilutions). When we used IEM to examine the relationship of the Australian virus to those viruses, we found a similar pattern. Our isolate was closely related to PLV-g and progressively less related to PVS, PLV-f, and PVM.

Based on particle morphology, serological reactions, host studies, and cytopathology, we believe the carlavirus in passionfruit in New South Wales and Queensland is PLV. The virus occurs in the major passionfruit-growing areas in eastern Australia and has been present for at least 10 years. Many of the main cultivars are grown in all areas, and it is very likely the virus has moved primarily in budwood. This argument seems to be strengthened by the fact that, even in districts where PLV-infected grafted cultivars are growing, seedlings of cv. Panama growing apart from infected plants are apparently free from PLV. Further, PLV occurrence in $P$. suberosa, $P$. subpeltata, and feral seedling $P$. edulis is low. The low incidence of infection in seedlings indicates that the virus is either inefficiently transmitted by vectors or that the vectors are not attracted to those species.

The effect of PLV on production of Australian passionfruit is unknown. In Australia, PLV invariably infects passionfruit together with PWV. By analogy with PTN (13), a mixed infection of PWV and another virus would be expected to cause a decrease in yield of passionfruit over that of PWV alone.

\section{ACKNOWLEDGMENTS}

We thank C. Wetter and M. S. Elliott for the gift of antiserum to their isolates of Passiflora latent carlavirus, P. Ross and S. Newett for collecting samples from Queensland, and R. Fitzell and R. Loebel for sample collection in New South Wales.

\section{LITERATURE CITED}

1. Bos, L., and Rubio, H. M. 1971. Intracellular accumulation of Passiflora latent virus in Chenopodium quinoa. Neth. J. Plant Pathol. 77:145-153.

2. Brandes, J., and Wetter, C. 1963. Studies on the characteristics and relationships of Passiflora latent virus. Phytopathol. Z. 49:61-70.

3. Clark, M. F., and Adams, A. N. 1977. Characteristics of the microplate method of enzyme-linked immunosorbent assay (ELISA). J. Gen. Virol. 34:475-483.

4. Dubern, J., and Dollet, M. 1981. Groundnut crinkle virus, a new member of the carlavirus group. Phytopathol. Z. 101:337-347.
5. Francki, R. I. B., Mossop, D. W., and Hatta, T. 1979. Cucumber mosaic virus. CMI/AAB Descriptions of Plant Viruses No. 213. Commonw. Mycol. Inst./Assoc. Appl. Biol., Kew, England.

6. Hollings, M., and Huttinga, H. 1976. Tomato mosaic virus. CMI/AAB Descriptions of Plant Viruses No. 156. Commonw. Mycol. Inst./Assoc. Appl. Biol., Kew, England.

7. Koenig, R. 1982. Carlavirus group. CMI/AAB Descriptions of Plant Viruses No. 259. Commonw. Mycol. Inst./Assoc. Appl. Biol., Kew, England.

8. Magee, C. J. 1948. Woodiness or mosaic of passionfruit. Agric. Gaz. NSW 59:199-202, 208.

9. Milne, R. G., and Luisoni, E. 1975. Rapid high resolution immune electron microscopy of plant viruses. Virology 68:270-274.

10. Pares, R. D. 1988. Serological comparison of an Australian isolate of capsicum mosaic virus with capsicum tobamovirus isolates from Europe and America. Ann. Appl. Biol. 112:609-612.

11. Pares, R. D., Martin, A. B., and Morrison, W. 1983. Rhabdovirus-like particles in naturally infected Passiflora edulis Sims. Australas. Plant Pathol. 12:51-52.

12. Pares, R. D., and Whitecross, M. I. 1983. A critical examination of the utilisation of serum-coated grids to increase particle numbers for length determination of rod-shaped plant viruses. J. Virol. Meth. 7:241-250.

13. Pares, R., Martin, A., and Fitzell, R. 1985. Virus induced tip necrosis of passionfruit (Passiflora edulis Sims). Australas. Plant Pathol. 14:76-78.

14. St Hill, A. A., Zettler, F. W., Elliott, M. S. Petersen, M. A., Li, R. H., and Bird, J. 1992. Presence of Passiflora latent virus and a serologically distinct strain of maracuja mosaic virus in Passiflora spp. in Florida. Plant Dis. 76:843-847.

15. Taylor, R. H., and Greber, R. S. 1973. Passionfruit woodiness virus. CMI/AAB Descriptions of Plant Viruses No. 122. Commonw. Mycol. Inst./Assoc. Appl. Biol., Kew, England.

16. Taylor, R. H., and Kimble, K. A. 1964. Two unrelated viruses which cause woodiness of passionfruit (Passiflora edulis Sims). Aust. J. Agric. Res. 15:560-570. 